HoST - Journal of History of Science and Technology

Vol. 13, no. 1, June 2019, pp. 76-105

10.2478/host-2019-0004

\title{
Arsenical Pesticides in Early Francoist Spain: Fascism, Autarky, Agricultural Engineers and the Invisibility of Toxic Risks
}

\author{
José Ramón Bertomeu-Sánchez \\ López Piñero Interuniversity Institute, University of València \\ bertomeu@uv.es
}

\begin{abstract}
Lead arsenate was introduced on a massive scale in agriculture in Spain in the early 1940s. With the support of a network of agricultural engineers, the new Francoist state encouraged the production and use of lead arsenate as the main weapon against a newly arrived pest, the Colorado potato beetle. In this paper I discuss arsenical pesticides as sociotechnological products which played a pivotal role in the joint production of both chemical-based agriculture and the emerging Francoist regime in Spain during the 1940s. I review the campaigns organized by agriculture engineers and the making of the new National Register for Phytosanitary Products in 1942. The new regulations promoted research in pesticide quality control but also contributed to concealing the health hazards. This invisibilization of the risks took shape in the confluence of interests of the emerging Francoist state, the new pesticide industry, and the large network of agricultural engineers.
\end{abstract}

Keywords: pesticides, lead arsenate, Colorado beetle, Francoist Spain, science and fascism 


\section{Introduction}

Studies on the history of poisons and toxic products have blossomed during the last decade, and have covered an ever wider range of topics. Poisons have been the protagonists of many narratives, from the history of crime to environmental history and the history of public and occupational health. Though there is no denying that disciplinary borders remain in place, an increasing convergence has been seen in this growing historical literature in recent years, with the introduction of broader sets of protagonists including experts, decision-makers, activists, judges, polluters, and victims; the attention to the sociomaterial agency of toxic products; comparative studies on toxic hazards in different societies and historical periods; the blurred and contested borders connecting science, medicine, economic interests and politics; and a new focus on social conflicts marked by the striking asymmetries regarding epistemic tools, political power, economic resources and the access to mass media. ${ }^{1}$

One of the most productive areas of research has been the study of the history of agrochemicals and their effects on public health and the environment. The dominant narrative in the history of pesticides has focused on the DDT and the environmental controversy preceding the regulations in the 1970s in the United States. By and large, these narratives disregard other contexts, products, toxic risks, regulations and historical actors. This paper deals with a group of pesticides based on arsenic compounds which were introduced in agriculture at the end of the nineteenth century. In contrast to DDT, arsenic was a well-known poison that had been used by murderers for centuries. Indeed, historical studies of arsenic have mostly focused on its criminal uses and only recently have historians become interested in other areas such as its role in food poisoning, the toxic hazards created by arsenical pesticides for farmers and consumers, and the environmental consequences of its contamination of soil and water. ${ }^{2}$

In this paper, I discuss arsenical pesticides as sociotechnological products that played a pivotal role in the co-production of both chemical-based agriculture and the new Francoist regime

\footnotetext{
${ }^{1}$ For recent reviews of the literature, see Rachel Emma Rothschild, "The Turn towards Toxins: An Essay Review," Endeavour 40, no. 2 (June 2016): 128-30; Claas Kirchhelle, "Toxic Tales-Recent Histories of Pollution, Poisoning, and Pesticides (ca. 1800-2010)," NTM Zeitschrift für Geschichte der Wissenschaften, Technik und Medizin 26, no. 2 (June 2018): 213-29. More details on the approach adopted in this paper in José Ramón Bertomeu-Sánchez and Ximo Guillem-Llobat, "Following Poisons in Society and Culture (1800-2000): A Review of Current Literature," Actes d'historria de la ciència i de la tècnica 9 (2017): 9-36.

2 Jim Phillips and Michael French, "The Pure Beer Campaign and Arsenic Poisoning, 1896-1903," Rural History: Economy, Society, Culture 9 (1998): 195-209; Matthew Copping, "Death in the Beer Glass: The Manchester Arsenic-in-Beer Epidemic of 1900-1 and the Long-Term Poisoning of Beer," Journal of the Brewery History Society 132 (2009): 31-57; James Whorton, Before Silent Spring: Pesticides and Public Health in Pre-DDT America (Princeton (NJ): Princeton University Press, 1974); Nathalie Jas, "Public Health and Pesticide Regulation in France before and after Silent Spring," History and Technology 23, no. 4 (2007): 369-88.
} 
in Spain during the 1940s. Drawing on previous studies of agriculture and fascism, I explore a group of pesticides - lead arsenates - which were introduced under the aegis of the early Francoist policies that sought to bring together agriculture and industry. ${ }^{3}$ The politics of autarky played an important role both as an ideological goal (self-sufficiency) and as a response to a specific economic situation (commercial isolation) caused by the shortage of imported raw materials. Many Francoist politicians were persuaded that self-sufficiency could only be obtained by means of a centralized authoritarian regime able to enforce more effective practices in agriculture and at the same time promote the intensive exploitation of mineral resources and the development of national industry. In this process, the role of experts such as engineers in mining, public works and agriculture was seen as crucial. ${ }^{4}$

Therefore, the early years of the Francoist regime represent an excellent context for studying how public authorities, experts, polluters, activists and victims conceive and manage toxic hazards. ${ }^{5}$ In that period, arsenical pesticides were enthusiastically introduced in Spain, serving to reinforce the new regime while shaping the emergence of agrochemical industry in the country. They also paved the way for the arrival of new products such as DDT and mapped out Spain's later route towards the "pesticide treadmill" - that is, the marginalization of other forms of pest control and the emergence of new balances between short-term profits and longterm human and environmental costs. ${ }^{6}$ I am particularly interested in the changing processes

\footnotetext{
3 Tiago Saraiva, Fascist Pigs: Technoscientific Organisms and the History of Fascism (Cambridge, MA: The MIT Press, 2016). See also Tiago Saraiva and M. Norton Wise, eds., Special issue, Historical Studies in the Natural Sciences 40, no. 4 (2010). On Spanish engineering and the Francoist regime, see Lino Camprubí, Engineers and the Making of the Francoist Regime (Cambridge, MA: The MIT Press, 2014); Erik Swyngedouw, Liquid Power: Contested Hydro-Modernities in Twentieth-Century Spain (Cambridge, MA.: The MIT Press, 2015).

4 On these issues, see Tiago Saraiva and M. Norton Wise, "Autarky/Autarchy: Genetics, Food Production, and the Building of Fascism," Historical Studies in the Natural Sciences 40, no. 4 (2010): 419-28; Santiago Gorostiza, "Mobilising Nature between Democracy and Fascism. An Environmental History of the Spanish Civil War and the Legacies of the Francoist Autarky" (PhD diss., Universidade de Coimbra, 2017).

5 I rely here on the discussion on "industrial hazards regimes" by Christopher Sellers and Joseph Melling, Dangerous Trade. Histories of Industrial Hazards across a Globalizing World (Philadelphia: Temple University Press, 2012); and "modes of government of risks" by Soraya Boudia and Nathalie Jas, "Gouverner un monde contaminé. Les risques techniques, sanitaires et environnementaux," in Histoire des sciences et des savoirs. Le siècle des technosciences, eds. Christophe Bonneuil and Dominique Pestre, 380-97 (Paris: Seuil, 2015).

${ }^{6}$ Robert van den Bosch, The Pesticide Conspiracy (Berkeley: University of California Press, 1989); Angus Wright, The Death of Ramón González: The Modern Agricultural Dilemma, Revised edition (Austin: University of Texas Press, 2005); Douglas L. Murray, Cultivating Crisis: The Human Cost of Pesticides in Latin America (Austin, Texas: University of Texas Press, 1995).
} 
of visibilization/invisibilization of toxic hazards in different settings: the workplace, the food market, and the environment. ${ }^{7}$

With these issues in mind, the present paper focuses on the role of agricultural engineers in the emergence of this "pesticide treadmill." Before offering a collective portrayal, in the first section I describe other expert groups interested in pest control in early twentieth-century Spain: forest engineers, entomologists, and public health physicians. I also review the reluctance of farmers to adopt the new pesticides in these early years. The next section discusses how agricultural engineers established themselves as the most powerful expert group in pest control during the first years of the Francoist regime. I go on to describe the arrival of a key non-human protagonist - the Colorado beetle, which crossed the Pyrenees at the end of the 1930s - and discuss how the Francoist authorities managed the challenges posed by this new pest during its early years, a period marked by the policy of autarky, famine, and brutal political repression. I review the various resources mobilized by agricultural engineers in order to establish lead arsenate as a standard product in agriculture. In response to concerns regarding pesticide adulteration and hazards for crops, regulations in the pesticide market were introduced in 1942; but the physical risks to farmers were barely mentioned, even when the health hazards could no longer be concealed due to the numerous cases of poisoning, food adulteration accidents, and evidence of damage to wildlife. I claim that the new regulations promoted new research into pesticide quality control and the development of the Spanish pesticide industry, but also contributed to concealing the health risks for farmers and consumers.

\section{Before DDT: lead arsenate in Spain}

Lead arsenate was introduced in agriculture at the end of the nineteenth century. Its first uses are connected with the campaigns against the gypsy moth in Massachusetts in the 1890s. ${ }^{8}$ Soon it became one of the most popular of a new group of arsenic-based pesticides, alongside Paris green, London purple, and calcium arsenate. The new pesticides were conceived to

\footnotetext{
7 On agnotology, see Robert N. Proctor and Londa Schiebinger, eds., Agnotology: The Making and Unmaking of Ignorance (Stanford, CA: Stanford University Press, 2008). On the neglect of hazards related to pesticides in farmers, see Nathalie Jas, "Pesticides et santé des travailleurs agricoles en France. Questions Anciennes, Nouveaux Enjeux," Le Courrier de l'environnement de l'INRA 59 (November 2010): 47-59. See also Emmanuel Henry, Ignorance scientifique et inaction publique: Les politiques de santé au travail (Paris: Presses de Sciences Po, 2017).

${ }^{8}$ Robert J. Spear, The Great Gypsy Moth War: The History of the First Campaign in Massachusetts to Eradicate the Gypsy Moth, 1890-1901 (Amherst: University of Massachusetts Press, 2005), 120-26, $147-$ 148. See also Frederick Rowe Davies, Banned. A History of Pesticides and the Science of Toxicology (New Haven: Yale University Press, 2014), 4-11. For previous uses of arsenical compounds in agriculture, see Matthew Holmes, "Melancholy Consequences: Britain's Long Relationship with Agricultural Chemicals Since the Mid-Eighteenth Century," Environment and History 25, no. 1 (February 2019): 117-134.
} 
combat insect pests produced by the combination of new agricultural ecosystems such as the widespread extension of monocultures, domestic and foreign food markets, and the new industrial transport system which favoured the spread of insects previously isolated in certain areas. Many years before DDT, these pesticides were also applied in health campaigns against malaria and other diseases transmitted by insect vectors. ${ }^{9}$

Early twentieth-century Spanish agriculture tends to be described as backward, archaic, inefficient, and unproductive. Among the reasons usually mentioned are the limited use of machinery and agrochemicals. Scarce attention has been paid to technological changes before the 1960s, when the combined effects of economic development and the Green Revolution are believed to have produced a new scenario, in which Spain became one of the European countries with the highest levels of pesticide use at the beginning of the twenty-first century. ${ }^{10}$ In recent decades this dominant view has been reassessed by new research on the history of Spanish agriculture which takes into account environmental constraints, regulatory frameworks, additional economic factors, social processes of decision-making, and regional variations. Additional historical actors have been taken into account with reference to the introduction of new seeds, inputs, techniques and practices in the broad range of social contexts and agricultural ecosystems in the Iberian Peninsula. ${ }^{11}$ This revised view of technological change is also important when dealing with the advent of arsenical pesticides. In this case, the "backwardness" narrative has its roots in the writings of early twentieth-century agricultural engineers who lamented the scarce use of fertilizers and pesticides in Spain. They also celebrated the massive arrival of lead arsenate in their country in the 1940s, some decades after its first application in the United States and Canada, and at a time when it was in common use in France and other European countries. ${ }^{12}$

The case under study here offers further evidence of substantial technological changes in Spanish agriculture during the first decades of the twentieth century, along with other examples (for instance, fertilizers) recently highlighted by historians of agriculture. Also in tune with these new historiographical trends, the historical records available suggest substantial

\footnotetext{
9 Whorton, Before Silent Spring, 3-34. Jas, "Public Health and Pesticide Regulation."

10 The master narrative including these ingredients is James Simpson, La agricultura española (17651965), La larga siesta (Madrid: Alianza, 1997). On the use of pesticides in Spain at the beginning of the twenty-first century, see the data provided by Eurostat in https:/ec.europa.eu/eurostat/web/productseurostat-news/-/DDN-20181015-1 (accessed December 28, 2018).

${ }_{11}$ Josep Pujol, ed., El pozo de todos los males: sobre el atraso en la agricultura española contemporánea (Barcelona: Crítica, 2001).

12 On Canada see Paul W. Riegert, From Arsenic to DDT: A History of Entomology in Western Canada (Toronto: University Toronto Press, 1980); George M. Cook, “'Spray, Spray, Spray!': Insecticides and the Making of Applied Entomology in Canada, 1871-1914," Scientia Canadensis 22 (1998-1999): 7-50. On France, Rémi Fourche, "Contribution à l'histoire de la protection phytosanitaire dans l'agriculture française (1880-1970)” (PhD diss., Université Lumière Lyon 2, 2004).
} 
regional variations in the first uses, types and quantities of pesticides in Spain. ${ }^{13}$ However, the chronology of the uses of arsenical pesticides defies the persistent views regarding the first decade of the Franco regime, usually regarded as "years of delay" during which technological change lost momentum due to the alteration of the economic, social and institutional bases which had earlier prompted agriculture innovations during the previous three decades. ${ }^{14}$ The first references to lead arsenate in Spanish agronomic literature date from around 1910. It was applied against pests affecting a variety of crops such as grapes, olives and apples during the 1920s and 1930s, but its use remained very limited until 1940, when Colorado beetles arrived in Spain. In fact, it was during the first years of the Franco regime that arsenical pesticides were introduced on a massive scale in Spain, due to the issues I will discuss in the following pages.

Before being used in agriculture, arsenical pesticides were first tested in experimental farms. As early as 1909 Jaume Nonell Comas, a Catalan agricultural engineer who ran the agronomic service in Barcelona, explored the uses of arsenates against grapevine pests (Altica ampelophaga). Different arsenates were also applied in the 1910 s against pests in olive trees. ${ }^{15}$ The first reports written by agricultural engineers included details on the purposes of the new pesticides, and on the methods and quantities that should be used. They also emphasized the toxic nature of these agents, recommended the use of colorants to distinguish the pesticides from foodstuffs and urged caution in preparing mixtures and spraying: machinery and workers' hands had to be carefully cleaned, and toxic products had to be labelled and separated from food, cattle and children; workers were instructed to handle the products with the strictest care; and some agricultural engineers even recommended that only trained workers should be allowed to prepare products as dangerous as lead arsenates. In fact, special courses were created in the 1910s for training "capataces fumigadores" (fumigators). Although mostly focused on cyanide fumigations, these practical courses also included a general overview of pest control and presented instructions for spraying with arsenates. ${ }^{16}$

By the beginning of the 1920s, arsenical compounds (particularly Paris green and sodium arsenate) started to be used as pesticides in Spanish agriculture. Reports on the virtues of lead

\footnotetext{
${ }^{13}$ See reports on pest control in different areas of Spain in the series Agricultura (61), Archivo General de la Administración (hereafter cited as AGA).

${ }^{14}$ Lourenzo Fernández Prieto and Josep Pujol, "El cambio tecnológico en la historia agraria de la Espańa contemporánea," Historia agraria 24 (2001): 59-87, on 68.

15 El Siglo Futuro, February 11, 1909, 3. See Ignaci Clarió-Soulán and Jaume Nonell Comas, MemoriaResumen de los trabajos realizados en la extinción de las plagas del campo durante el año 1910 (Barcelona: Fomento, 1910); and Ignaci Clarió-Soulán; Jaume Nonell Comas, Formulario de terapéutica agrícola (Barcelona: Fomento, 1915), 95. See Alejandro Cabrera González, "El Museo de Patología Vegetal y Terapéutica Vegetal de Barcelona ¿Un museo activo, útil y efímero?” (Master's thesis, Universitat Autònoma de Barcelona, 2017).

${ }^{16}$ See the paper by Ximo Guillem in this volume for further details.
} 
arsenates became increasingly frequent in the agronomic literature as well as in publications addressed to farmers. International meetings on pest control, such as the International Olive Fly Conference held in Madrid in 1923, also served to popularize the new chemical methods. The various techniques were discussed by agricultural engineers, who expressed contrasting views on the uses of arsenic compounds. Other methods for pest control, including biological control, were also mentioned and discussed, and other national regulations on the uses of arsenic compounds in agriculture were reviewed. ${ }^{17}$

Participants at the Madrid conference included famous entomologists such as Paul Marchal from France and Leland O. Howard from the United States. ${ }^{18}$ Howard had already visited Madrid, where he had met members of the Phytopathological Station located in this city. During the 1923 conference, Howard had "a long talk" with "the veteran Ignacio Bolivar and his son, Cándido Bolivar" and also with Ricardo García Mercet. He acknowledged that these authors "had done, and were doing, admirable work with certain groups of parasites." 19 These naturalists, who had strong ties with the National Museum of Natural History, played a major role in the emergence of Spanish entomology, which was gaining momentum during the 1920s, and they organized an important international meeting in Madrid in 1935. Their work, however, was seriously affected by the Civil War, as many of them faced political repression or were forced into exile. Using the entomologic collections and libraries of these scientists, the new Francoist regime created a new institute (Instituto Español de Entomología) in 1941, under the direction of a forest engineer, Gonzalo Ceballos. The broad-ranging, general approach that had characterized the centre in its early days was now replaced by a narrow focus on forest pest

17 Conférence internationale de lutte contre la mouche de l'olive (Madrid: Gráficas Reunidas, 1923). See also El Progreso Agrículo y Pecunario, August 31, 1923, 531-535.

18 On economic entomologists and pest management see Paolo Palladino, Entomology, Ecology, and Agriculture: The Making of Scientific Careers in North America, 1885-1985 (Amsterdam: Harwood Academic Publishers, 1996); Thomas R. Dunlap, DDT: Scientists, Citizens, and Public Policy (Princeton, N.J: Princeton University Press, 1981); Whorton, Before Silent Spring; Riegert, From Arsenic to DDT; Lukas Straumann, Nützliche Schädlinge: Angewandte Entomologie, Chemische Industrie und Landwirtschaftspolitik in der Schweiz 1874-1952 (Zürich: Chronos, 2005), 134-51; Cook, "'Spray, Spray, Spray!" On the previous agronomic research in France and Germany, see Nathalie Jas, Au carrefour de la chimie et de l'agriculture: Les sciences agronomiques en France et en Allemagne, 1850-1914 (Paris: Archives contemporaines, 2011).

19 See Leland Ossian Howard, Fighting the Insects; the Story of an Entomologist (New York: The Macmillan Company, 1933), 207-9. See also his personal portrayal of Spanish pest control services in Leland Ossian Howard, A History of Applied Entomology (Washington: The Smithsonian Institution, 1930), 327-30. 
control by means of pesticides and aerial fumigations during the 1940s and 1950s. ${ }^{20}$

As a forest engineer, Ceballos was part of the other important group of experts who, along with entomologists and agricultural engineers, were interested in pest control. With its roots in the previous decade, the new Office for Forest Pest Control (Servicio de Estudio y Extinción de Plagas Forestales) was created in the early 1920s under the leadership of the forest engineer Manuel Aulló Costilla. Forest engineers had made abundant use of lead arsenate in the campaigns against the gypsy moth in southern Spain. Trained as an entomologist, Aulló started to work on pest control in the early 1910s. He was well-versed in recent developments in pest control in the United States, including both chemical and biological methods, but he relied heavily on lead arsenate during the forest pest campaigns. Thanks to the work of mediators like Ceballos, who was professor at the Forest School but also had research interests in general entomology, in the 1930s the Forest Office came into contact with the group of entomologists working at the National Museum of Natural History in Madrid, including Bolívar and García Mercet. Like the entomological section at the museum, the office was abolished at the beginning of the Civil War and, during the 1940s, most of its responsibilities were transferred to the new Institute of Entomology and other centres. ${ }^{21}$

The other area in which arsenates were used widely in Spain was the campaign against malaria in the 1920s. A special commission (Comisión Central Anti-Palúdica) was created and several methods were explored, including the use of oils and arsenates (Paris green) against the mosquito. Experiments were performed in controlled fields and the results were reported by epidemiologists and parasitologists. The use of Paris green in malaria control was limited by its

20 Carolina Martín Albaladejo, Antonio Notario Gómez, and Alfonso V. Carrascosa Santiago, "El Instituto Español de Entomología (CSIC) y la multitud molesta," Asclepio 68, no. 1 (June 2016): 125; Alberto Gomis Blanco, "Mimbres para otro cesto: De la Sección de Entomología del Museo Nacional de Ciencias Naturales al Instituto Español de Entomología," Boletín de la Real Sociedad Española de Historia Natural. Sección biológica 108, no. 1-4 (2014): 37-47. The changes in the dominant expert communities, research programs and purposes raise serious questions about the quantitative approach offered in Carolina Martín Albaladejo and Borja Sanchiz, "Consequences of the Spanish Civil War for Entomology: A Quantitative Example of Abrupt Alteration in Scientific Research Dynamics," Isis 108, no. 2 (May 2017): 335-52. I particularly disagree with the idea that "entomology, as it was practiced at the time, was a zoological discipline engaged in taxonomic and faunistic research, with no industrial or economic relevance" (p. 336). See the critical literature quoted in note 18 for completely different views.

${ }^{21}$ Royal Order (hereafter RO) of 17 January 1921 and Royal Decree of 10 November 1922. On the campaigns see El Imparcial, July 4, 1925 and Manuel Aulló, "Problemas nacionales. Organización de los servicios contra plagas y enfermedades de las plantas," El Auxiliar de la Ingeniería y Arquitectura 96, (1925): 78-80. 
high cost; in fact, spraying was suspended in many areas affected by the mosquito in the early 1930 s and was finally cancelled during the years of the Civil War. ${ }^{22}$

\section{Silenced resistances}

As the use of arsenates spread in agriculture, public health and forest management, farmers and consumers expressed concern regarding the potential hazards of these agents. In the public imagination arsenic was well known as a poison used by criminals, and a series of accidents reported during those years (the most famous of them involving apples in the United States in the mid-1920s) stoked the fires still further. ${ }^{23}$ During these first decades of the twentieth century, the hazards of arsenates were discussed in the general Spanish press, which also reported the French debate on the uses of arsenic compounds in agriculture. ${ }^{24}$ In addition, experts noted the reluctance of farmers to adopt the new arsenical pesticides. Daniel Nagore, an agricultural engineer who ran a large spraying campaign against sugar beet pests in 1923, found that farmers were frightened by the "mortal effects" of arsenic and that some of them were familiar with the French legal restrictions concerning its use in agriculture. ${ }^{25}$ Another agricultural engineer, José Cruz Lapazarán, who frequently offered advice on arsenical spraying in agronomic journals during the 1920s, wrote a long answer in a trade newspaper to the concerns expressed by farmers. He offered many technical details on the chemical analysis of sprayed fruits, concluding that the quantities of arsenic detected in apples were so small that they could not be harmful to humans or animals. According to Lapazarán, the concerns with arsenical compounds in agriculture were merely "products of the rural imagination," which was always prone to equate innovation with evil. ${ }^{26}$

${ }^{22}$ Sadí de Buen, Trabajos sobre el empleo del Verde París (Madrid: José Molina, 1927); Eliseo de Buen, Indicaciones prácticas para el empleo del "Verde de Schweinfurt" (Verde Paris) (Madrid: José Molina, 1929). See also Juan Gil Collado, Los insectos hematófagos y transmisores de enfermedades (Madrid: José Molina, 1927). For a historical overview, see Esteban Rodríguez Ocaña, ed., La acción médico-social contra el paludismo en la España metropolitana y colonial del siglo XX (Madrid: Consejo Superior de Investigaciones Científicas, 2003), 283-94.

${ }^{23}$ See Dunlap, DDT, 43-48; James E. McWilliams, American Pests: The Losing War on Insects from Colonial Times to DDT (New York: Columbia University Press, 2008), 151-57; Whorton, Before Silent Spring, 129-38.

${ }^{24}$ El Siglo Futuro, May 19, 1909 (on French debates) and January 22, 1910 (on the effect of arsenic on bees). On this latter issue, see the paper by Anne Jorunn Frøyen in this volume. On the French debate see Fourche, Contribution à l'histoire de la protection phytosanitaire dans l'agriculture française (18801970), 55-76.

${ }^{25}$ Daniel Nagore, "El Arsénico," El Progreso Agrícola y Pecuario 30 (1924): 510-11. See also Daniel Nagore, El empleo de compuestos arsenicales para combatir las plagas del campo (Madrid: Fomento, 1924).

${ }^{26}$ El Progreso Agrícola y Pecuario, June 7, 1920. Other examples of resistance among farmers can be found in El Progreso Agricola y Pecuario, May 22, 1930, 367-368. 
This resistance was also mentioned in the general press. Answering similar concerns of consumers in newspapers, an anonymous author reviewed the studies on arsenic in apples and wine, and concluded that the small amounts detected could only be "beneficial for public health." ${ }^{27}$ However, when the pharmacist Juan Casas reviewed the various causes of food poisoning in 1932, he mentioned the risks of lead arsenate in grapevines and of its presence in wine. ${ }^{28}$ The issue came to the attention of the academic community due to a high-profile case of poisoning in France, apparently caused by Spanish wine. With such important commercial interests at stake, a large group of French and Spanish experts participated in the controversy on the risks of arsenical compounds in viticulture, and made recommendations ranging from its total prohibition to its restricted use in controlled conditions. ${ }^{29}$

In 1928, Pedro Hercé, an agricultural engineer whose work focused on pesticide quality control, complained of the limited use of pesticides in Spanish agriculture, while acknowledging an increase in their consumption in the past few years. Hercé expressed is worry that the growing demand for pesticides had also raised the circulation of poor quality, adulterated or fraudulent products, some of which lacked real pesticidal properties and were even harmful for plants; this was, he said, a major source of the farmers' aversion to their use. Hercé recommended regular controls of the quality of commercial insecticide products, particularly the amount of active ingredients, so they could be both effective against pests and harmless to plants. He called for experimental studies on these pesticides and, in fact, throughout the 1920s and 1930s he and other colleagues performed many experiments with different mixtures of arsenates. ${ }^{30}$ Hercés views on quality control were moulded according to the US regulations of the beginning of the twentieth century. ${ }^{31}$ Many other agricultural engineers supported the regulation of these products, along the lines of the US model; in Spain, several minor controls were implemented in the 1920s and 1930s but the most important ones were introduced in the early 1940s, just after the Spanish Civil War. ${ }^{32}$

\footnotetext{
27 Severo Gómez Nuñez, “Las plagas en la agricultura,” Alrededor del Mundo, March 22, 1930.

${ }^{28}$ Juan Casas Fernández, Investigaciones quimicas en intoxicaciones alimenticias (Madrid: Real Academia de Farmacia, 1932).

29 See Ignacio Suay-Matallana and Ximo Guillem-Llobat, "Poisoned Wine: Regulation, Chemical Analyses, and Spanish-French Trade in the 1930s," Ambix 65, no. 2 (2018): 99-121.

${ }^{30}$ Jesús Ignacio Catalá-Gorgues and Ximo Guillem-Llobat, "Control de plagas y desarrollo institucional en la estación de patología vegetal de Burjassot (Valencia) (1924-1931)," Asclepio 58, no. 1 (2006): 249-80. See also Miguel Cabo, A estación de fitopatoloxía agrícola da Coruña (1926-1951) (Santiago: Xunta de Galicia, 1999).

31 Pedro Hercé, "Notas sobre análisis químico de insecticidas arsenicales," Boletín de Patología Vegetal y Entomología Agrícola 3 (1928): 131-134; Pedro Hercé, "El arsénico soluble de los insecticidas arsenicales," Boletín de Patología Vegetal y Entomología Agrícola 7 (1934): 166-169.

32 José del Cañizo, "Los insecticidas en agricultura. Reglamentación necesaria," $A B C$, August 3, 1929. Concerning regulations in 1924, 1929 and 1932 see Dirección General de Agricultura, Plagas Del Campo. VI. Registro de Productos y Material Fitosanitario (Madrid: Ministerio de Agricultura, 1953), 22-24.
} 


\section{Agricultural engineers in the early Francoist Regime}

In the previous sections, we have seen that pest control management during the first decades of the twentieth century involved several different expert communities: agricultural and forest engineers, general and economic entomologists, and public health physicians. Among them, agricultural engineers attained the major role in pest control during the early years of the Francoist Regime. With its roots in nineteenth-century agronomic research, Spanish agricultural engineering gained momentum at the beginning of the twentieth century thanks to the Pest Control Act (1908), the opening of new teaching centres, the development of the National Institute for Agronomic research, the founding of research field stations (including several "Granjas experimentales" and "Estaciones Fitopatólogicas"), and the consolidation of a network of provincial agricultural sections led by an agricultural engineer. By the mid-1930s, just before the Spanish Civil War, some 400 agricultural engineers were appointed in these different positions, making this one of the most numerous engineering corps in Spain. Apart from their involvement in pest control, agricultural engineers played a major part in testing new inorganic fertilizers, running research on plant breeding, and introducing new seeds and agricultural machinery - the key issues, in their eyes, in the process of the "modernization" of Spanish agriculture. ${ }^{33}$

The period of the Second Republic (1931-1936) was a difficult one for the agricultural engineers. On the one hand, they were compelled to participate in the social debates concerning agriculture, in particular in the debates on land ownership and the Agrarian Reform Act. This involvement questioned the idea of their "technical neutrality," one of the pillars of the corps' public image. On the other hand, the Ministry of Agriculture, which was set up as a separate government department in 1933, offered new career opportunities for agricultural engineers, whose numbers reached their peak in those years. In 1935, new regulations expanded the role of provincial agricultural sections and the experimental land stations to include the quality control of fertilizers. ${ }^{34}$

Agricultural engineers played an increasing role in pest control during the 1930s. Being in charge of the provincial agricultural sections, they were required to survey and report any "negligence"

\footnotetext{
33 On experimental field stations, see Gorgues and Llobat, "Control de plagas." For a general overview of Spanish agricultural engineers see Juan Pan-Montojo, Apostolado, profesión y tecnología: una historia de los ingenieros agrónomos en España (Madrid: Asociación Nacional de Ingenieros Agrónomos, 2005). See also Jordi Cartañà i Pinén, Agronomía e ingenieros agrónomos en la España del siglo XIX (Barcelona: El Serbal, 2005).

34 Gaceta de Madrid, 2 March 1935, 1839-1843. On fertilizers see Josep Pujol, "La difusión de los abonos minerales y químicos hasta 1936: el caso español en el contexto europeo," Historia agraria 15 (1998): 143-84.
} 
regarding pest control. ${ }^{35}$ They published annual reports on their activities, and a new journal was created (the Boletin de fitopatologia y entomologia agricola), which published many papers on field and laboratory research. In this journal, arsenic products were recommended for exterminating an increasing number of pests: locusts, fruit flies, cutworm, almond-tree moths, beet armyworm, and so on. Official reports on pest control published during the 1930s also offer evidence on the growing use of arsenic compounds along with other chemicals such as cupric salts, nicotine, sulphurs, cyanide, and so on. Agricultural engineers gave lectures, provided materials and spraying equipment, published guidelines for action against particular pests and sent information on the pests affecting the different provinces every year to the government. ${ }^{36}$

In addition to their role in the introduction of pesticides, many agricultural engineers also carried out research in alternative forms of pest control, particularly in plant breeding (new varieties more resistant to pests or plant diseases) and biological control (for instance, the introduction of natural parasites of the insects). The entomologists mentioned above such as Ricardo García Mercet and Ignacio Bolívar and his son Cándido Bolívar, sometimes in collaboration with agricultural engineers, also popularized many biological methods, including the introduction of microorganisms, poisoning fungi, or predatory insects. ${ }^{37}$ In several stations, for instance in Burjassot (València), agricultural engineers performed field experiments designed to acclimatize the natural parasites of bugs affecting citrus trees such as Planococcus citri (citrus mealybug) and other pests such as Icerya purchasi (cottony cushion scale) or Chrysomphalus dyctiospermi (red scale). In Barcelona, similar studies were developed against apple aphids, employing the parasitoid Aphelinus mali, which was also mobilized in campaigns in A Coruña, València and the Basque Country during the 1930s. ${ }^{38}$

The critical years of the Civil War and the following decade, marked by brutal political repression, affected the communities dealing with pest control in very different ways. While famous entomologists such as Cándido Bolivar were forced into exile, most of the agricultural

${ }^{35}$ Gaceta de Madrid, 5 February 1929, 1041-1046. Further details on the regulations on pest control in Juan Peinado Vacas, "Un paseo comentado por la historia de la normativa fitosanitaria agrícola en Espańa: de la Ley de Plagas de 1908 a la actualidad," Boletín de Sanidad Vegetal. Plagas 23, no. 4 (1997): 613-25.

${ }^{36}$ Dirección General de Agricultura, Memoria del Servicio Fitopatológico Agrícola: año 1932 (Madrid: Ministerio de Agricultura, 1933).

37 The importance of biological methods of pest management is confirmed in textbooks such as Ricardo García Mercet, La lucha contra los insectos (Madrid: Espasa-Calpe, 1936), 7-30.

${ }^{38}$ Pedro Urquijo Landaluce, "La lucha contra el 'pulgón lanígero' del manzano," Agricultura 71 (1934): 730-32. See Cabo, A estación de fitopatoloxia, 226-231, for the important work developed at the experimental station in A Coruña. See also Miguel Benlloch, "La lucha contra las plagas del campo. Su evolución en los últimos treinta años," Boletín de la Asociación Nacional de Ingenieros Agrónomos 3, no. 52 (1954): 10-11. See also Jordi Cartañà, "Jaume Nonell i Comes i la introducció de la lluita biològica," in Actes de Les III Trobades d'Historia de la Ciència i de la Tècnica, 121-26 (Barcelona: SCHCT, 1995). 
engineers remained in Spain and were able to pursue successful careers: only a small number (around ten percent) suffered political persecution. The rest remained in Spain and cooperated, with varying degrees of enthusiasm, with the new Francoist regime. In fact, their role in politics increased, particularly in areas related to agriculture. Two ministers of agriculture (Carlos Rein Segura and Rafael Cavestany) were agricultural engineers, while the head of the service of agriculture Manuel Goytia Angulo was a member both of the Falange (the fascist party) and of the Spanish parliament. ${ }^{39}$ The reform of the National Institute of Agronomic Research in February and March 1940 established a large, centralized network under the control of agricultural engineers, comprising experimental farms, phytopathological stations, horticultural centres, agro-chemistry laboratories, wine, rice and olive research stations, and so on. ${ }^{40}$

Like other "Franco engineers," agricultural engineers enjoyed many opportunities to develop their modernization projects for Spanish agriculture. At the same time, they helped to bolster the new authoritarian regime thanks their expert knowledge of irrigation, transportation and agriculture. ${ }^{41}$ The marginalization of other groups such as the entomologists of the Museum of Natural History paved the way for the increased use of pesticides and the exclusion of other forms of pest control. And these trends were exacerbated by the arrival of a non-human protagonist: the Colorado beetle, which posed a major threat to the potato, one of Spain's most important crops.

\section{The Colorado beetle comes to Spain}

Colorado potato beetles, along with gypsy moths, were the most important targets of lead arsenate. The beetles had moved from the west to the east coast of the United States during the late nineteenth century and had reached Britain, France, and Germany by the beginning of the twentieth. Like many other countries, Spain implemented regulations to prohibit the importation of potatoes from America and other infected countries as early as $1875 .{ }^{42}$ In spite of drastic measures (field burning, extended pesticide use, control of exports, protection areas, and so on), the pest extended in France during the late 1920s and reached the Pyrenees in

39 Pan-Montojo, Apostolado, profesión y tecnología, 232-46; Daniel Lanero and Lourenzo Fernández Prieto, "Technology Policies in Dictatorial Contexts: Spain and Portugal," in Agriculture in Capitalist Europe, 1945-1960: From Food Shortages to Food Surpluses, eds. Carin Martiin, Juan Pan-Montojo, and Paul Brassley, 165-185 (Abingdon: Routledge, 2016), 172-73.

40 See Agricultura 94 (February 1940): 79-80, Boletin Oficial del Estado (hereafter BOE), 17 February 1940.

${ }^{41}$ Camprubí, Engineers and the Making of the Francoist Regime; Swyngedouw, Liquid Power, 116-20.

${ }^{42}$ RO of 2 March 1875, Gaceta de Madrid, 16 March 1875. See Esteban Boutelou-Soldevilla, "La Dorífora, escarabajo del Colorado o de la patata," Gaceta Agrícola del Ministerio de Fomento 5 (1877): 63-66; and Gaceta de Madrid, 16 January 1878. On the pest and its first developments see John F. M. Clark, "The Eyes of Our Potatoes Are Weeping: The Rise of the Colorado Beetle as an Insect Pest," Archives of Natural History 34 (2007): 109-28. 
the 1930s, alarming the Spanish authorities and obliging them to restrict the importation of potatoes and to establish points of control all along the French border. Agricultural engineers also participated in the first International Conference on the Colorado Beetle held in Paris at the beginning of June 1932. ${ }^{43}$ José del Cañizo, a leading member of the Madrid Experimental Field Station, published a long review of the conference along with several leaflets and articles in agronomic journals and newspapers. In these and other publications, farmers were instructed to report any suspicious bugs and to send samples to the provincial agronomic sections or to the nearest phytopathological station. ${ }^{44}$

The first case was detected in Maçanet de Cabrenys (northern Catalonia, near the Pyrenees) during the summer of 1935. Drastic steps were taken: the area was isolated, the potato harvest was destroyed, and all the surrounded area $(40 \mathrm{~km})$ was submitted to arsenic pesticides. This first episode was successfully contained, but the frustrated military coup against the democratic government in July 1936, which unleashed the Spanish Civil War, dramatically reduced the resources for controlling the pest. Potato beetles also appeared in northern Spain but were not reported by farmers, either because they did not recognize the insect or because they were afraid of the consequences of informing the authorities - namely, the destruction of their harvests and the burning of the surrounding areas. This was a scenario that filled them with terror due to the widespread famine of the time. ${ }^{45}$

The beetles were a particular source of alarm because of the increasing significance of potato production in Spanish agriculture, which had become the second most important crop (after wheat) in the years before the Civil War. According to the report by the agricultural engineer José María Díaz de Mendivil, potato production had risen from 3.1 million tonnes in 1910 to 48 million tonnes in 1936, thanks to a similar increase in cultivated land (while productivity per acre remained low). Like other agricultural engineers during the 1930s, Díaz de Mendivil worked on new potato seeds created by recent genetic research, performing field experiments in Iturrieta (Basque Country), where a research centre focused on potato breeding was set

43 Dirección General de Agricultura, Plagas del campo: 1932, 253-250. Due to the Civil War, Spain did not join the international committee established at the end of 1930s under the supervision of the Institute of Rome. See Straumann, Nützliche Schädlinge, 162-70; Raymond Mayné, ed., Comptes rendus de la IVième conférence du Comité international pour l'étude en commun de la lutte contre le doryphore: Wageningen, les 2, 3 et 4 février 1939 (Wageningen: Plantenziektenkundige Dienst, 1939).

44 José del Cañizo, "La Dorífora de la patata en Francia. Grave peligro para nuestra agricultura," Agricultura 44 (1932): 495-97; Dirección General de Agricultura, Plagas del campo 1932, 235-50; García Mercet, La lucha contra los insectos, 55-60; Jaume Nonell Comas and Antoni Bertran, El escarabajo de la patata (Barcelona: Estación de Fitopatología Agrícola, 1936). On Galicia see Cabo, $A$ estación de fitopatoloxía, 234-239. On France, see Rémi Fourche, "Internationalisation des traitements arsenicaux: des doryphores américains aux abeilles françaises (1868-1922)," Histoire \& Sociétés Rurales 47, no. 2 (2017): 137-76.

45 See Agustín Alfaro Moreno, "El escarabajo de la patata (Leptinotarsa Decemlineata Say)," Boletín de Patología Vegetal y Entomología Agrícola 10 (1941): 36-80. 
up, called the Estación para la Mejora de la Patata. The work of Díaz de Mendivil expanded in the early 1940s; thanks to his connections with the new authoritarian regime, he became an influential political leader in the Basque Country and was also appointed to key roles in institutions responsible for agriculture and, particularly, potato crops. ${ }^{46}$

The crisis in the international markets affected Spanish potato commerce, but domestic demand increased thanks to the development of new agroindustrial products whose importation was limited by World War II. The new government established new breeding programmes for the distribution of resistant varieties of potato (particularly to late blight) imported from Germany and the United Kingdom. Several areas of production were established under the control of the provincial agronomic sections, with the support of the new fascist agrarian trade unions. While encouraging potato production, the programme of "genetic modernism" was also a way to control rural populations and agricultural practices during the first years of the dictatorship: under the programme, labels and official certificates for seed potatoes ("patatas de siembra”) were introduced, permits were provided by the fascist trade unions, restrictions on the fields for cultivation were authorized by agricultural engineers, fines were imposed on recalcitrant potato breeders, practical courses were provided for farmers, quality controls were implemented, and fixed prices, taxes and subsidies were imposed. The arrival of the Colorado beetles represented a new challenge, which the advocates of further centralized control of rural areas used to their advantage. The new pest also strengthened the connections between the technocratic projects of the agricultural engineers and the policies of the Franco dictatorship. ${ }^{47}$

\section{Farmers, engineers and fascists}

Still a controversial topic in academic literature, many historians regard Franco's government as a "fascistized dictatorship" at least during the first years of its existence, when the influence of fascist groups and ideas was at its strongest. In rural Spain, the fascist policies lasted even longer thanks, in part, to the role of agricultural engineers in key political offices. ${ }^{48}$ The first years after the Civil War were marked by economic stagnation, deterioration of living standards and

46 José Maria Díaz de Mendivil, "Las variedades de patata y su influencia en el cultivo," Agricultura 96 (1940): 139-44; Carin Martiin, Juan Pan-Montojo, and Paul Brassley, eds., Agriculture in Capitalist Europe, 1945-1960: From Food Shortages to Food Surpluses (Abingdon: Routledge, 2016). See also José Maria Díaz de Mendivil, "El cultivo de la patata de siembra en España," in Congreso Nacional de Ingeniería Agronómica, 138-291 (Madrid: Asociación Nacional de Ingenieros Agrónomos, 1950).

47 See BOE, 9 November 1941; and the special issue of Agricultura 13 (February 1944): 142. On similar programs in Nazi Germany, see Saraiva, Fascist Pigs, 71-99. On "genetic modernism" in Vichy France, see Christophe Bonneuil and Frédéric Thomas, "Purifying Landscapes: The Vichy Regime and The Genetic Modernization of France," Historical Studies on Natural Sciences 40, no. 4 (November 2010): 532-68.

48 Ismael Saz, Las caras del Franquismo (Granada: Comares, 2013); Lanero and Fernández Prieto, "Technology Policies in Dictatorial Contexts: Spain and Portugal." 
extreme scarcity of imports, which seriously affected agrochemical products. Brutal political repression stamped out the activities that agrarian trade-unions had organized in rural areas since the early days of the century. In the 1940s, facing the policies of autarky and economic inactivity, Francoist politicians enlisted the help of agricultural engineers to devise substantial reforms in agriculture. These agrarian policies were largely based on State interventionism, corporatism (new farmers' unions) and market regulation (fixed prices, sales quotas, and rationing)..$^{49}$

With the prices of basic products under strict control, illegal production and black market activity skyrocketed. For many farmers (particularly those with connections to the new regime) this unofficial trade became their most important source of income. Paternalistic rhetoric was frequently used when addressing the rural population, and the new regime presented itself as a protective State that showed a particular concern for farmers. Several general agricultural programmes were implemented like the "Batalla del Trigo" (which recalled Mussolini's Battaglia del Grano) and the Service for the Control of Potato Seeds (Servicio Nacional de la Patata de Siembra) led by Díaz Mendivil..$^{50}$

The services for pest control were also reformed in August 1940, when a more centralized network of campaigns was introduced, and additional material and human resources were provided. Pests were classified according to their danger and incidence, with locusts and potato beetles being the ones that aroused the greatest concern in the 1940s. The fight against these two pests concentrated the largest resources in terms of manpower, pesticides and propaganda. Locusts and potato beetles were very different pests but, in both cases, arsenic played a major role in their control before the advent of DDT. Locusts were perhaps the most persistent and damaging pest in Spanish agriculture, and the circumstances of the war exacerbated their effects. In fact, the plague of 1939-1940 was regarded as one of the worst ever; the lack of pesticides (arsenates), sprayers, cars and manpower seriously undermined

\footnotetext{
${ }^{49}$ For differing points of view on agriculture in early Francoist years see Carlos Barciela López, "Algunas cuestiones de la agricultura española durante el franquismo," Areas: Revista internacional de ciencias sociales, no. 10 (1989): 91-93; Lourenzo Fernández Prieto, El apagón tecnológico del Franquismo: Estado e innovación en la agricultura española del siglo XX (Valencia: Tirant lo Blanch, 2007); Thomas Christiansen, The Reason Why: The Post Civil-War Agrarian Crisis in Spain (Zaragoza: Universidad de Zaragoza, 2012).

${ }^{50}$ BOE, 1 January 1942, 111-112 and BOE, 14 June 1942, 4290. See other regulations concerning fixed prices and seed potato tubers in Agricultura 13 (February 1944): 149. On Spanish agriculture, see Ana Cabana and Alba Díaz-Geada, "Exploring Modernization: Agrarian Fascism in Rural Spain, 1936-1951," in Agriculture in the Age of Fascism: Authoritarian Technocracy and Rural Modernization, 1922-1945, eds. Ignacio Fernández Prieto, Juan Pan-Montojo, and Miguel Cabo, 189-217 (Turnhout: Brepols, 2014). For more details on the battle of grain in other countries, see Saraiva, Fascist Pigs. See also Tiago Saraiva, "The Fascistization of Science," HoST - Journal of History of Science and Technology 3 (2009): 9-13.
} 
the regular management of the pest that had been undertaken by agricultural engineers in previous decades. ${ }^{51}$

The Colorado beetle was the other pest declared as a "public calamity" in the summer of 1940. Unlike locusts, potato beetles were newcomers to Spanish agriculture, even though the dangers they posed had been foreseen by agricultural engineers during the 1930s. Whereas locusts were visible and their effects well-known in rural areas, the control of Colorado beetles required the active collaboration of farmers whose crops remained apparently unaffected by the pest, at least during the first weeks. Farmers were instructed to follow "with due discipline" the procedures established by agricultural engineers: they had to inspect carefully their fields and "urgently report" any evidence of the pest, even if they did not see any danger for their crops. ${ }^{52}$

With the help of the political authorities, agricultural engineers carried out a large-scale campaign to discipline and train farmers in pest control management. The Service for the Sanitary Defence of Potato (Servicio de Defensa Sanitaria del Cultivo de la Patata) was set up in 1940 under the supervision of the agricultural engineer Agustín Alfaro Moreno. ${ }^{53}$ Alfaro Moreno published several papers on this issue during the following years, summarizing his experimental research on the effectiveness of different mixtures of pesticides in controlled fields, which confirmed the virtues of lead arsenate against the new pest. ${ }^{54}$

As the director of the new service, Alfaro Moreno coordinated an extended network of agriculture offices and phytopathological laboratories which had been created during the previous decades. In each province, the agriculture office was led by an agricultural engineer who was in charge of coordinating the campaign against the Colorado beetles. The campaign sought to alert

\footnotetext{
${ }^{51}$ Agricultura 96 (1940): 155-157. See also Miguel Benlloch, "Nuevas fórmulas de cebos envenenados contra la langosta," Agricultura 93 (1940): 10-11. On the history of the locust pest in Spain see Antonio Buj Buj, El estado y el control de plagas agrícolas: la lucha contra la langosta en la España contemporánea (Madrid: Ministerio de Agricultura, 1996).

52 Agustín Alfaro Moreno, "El escarabajo de la patata," Agricultura 11, no. 119 (1942): 119-25. The relevance of Colorado beetles in the emergence of British pest control services is remarked by John F.M. Clark, Bugs and the Victorians (New Haven: Yale University Press, 2009), chapter 7.

53 Alfaro Moreno, "El escarabajo de la patata." See C. Santiago-Álvarez, "El ingeniero agrónomo D. Agustín Alfaro Moreno (1903-1994), una figura clave de la fitopatología agrícola española," Boletín de Sanidad Vegetal. Plagas 24 (1998): 1033-48. See also Federico Bajo Mateos, El Servicio de Defensa Sanitaria del Cultivo de la Patata y la plaga del escarabajo americano (Madrid: Dirección General de Agricultura. Sección de Fitopatología y plagas del campo, 1946).

${ }^{54}$ Agustín Alfaro Moreno, La lucha química contra el escarabajo de la patata en España (Madrid: Dirección general de agricultura, 1944); Alfaro Moreno, "El escarabajo de la patata"; Agustín Alfaro Moreno, "La invasión del escarabajo de la patata al finalizar la campaña de 1941," Boletín de Patología Vegetal y Entomología Agrícola 11 (1942): 119-25; Agustín Alfaro Moreno, "La Invasión del escarabajo de la patata al iniciarse la campaña de 1943," Boletin de Patología Vegetal y Entomología Agrícola 12 (1943): 1-9; Agustín Alfaro Moreno, Una calamidad pública: La plaga del escarabajo de la patata (Almería: Jefatura agronómica, 1945).
} 
farmers to the dangers of the new pest, in the form of talks, practical courses, leaflets, articles in newspapers, radio broadcasting and even documentary films. Agricultural engineers also established services of surveillance for detecting new foci by means of selected collaborators. They also managed the acquisition of arsenical products and spraying equipment, which were distributed to farmers either free or at low prices in order to encourage further investment in these products. The new agrarian organizations (e.g. "Hermandades de Labradores y Ganaderos") also distributed lead arsenate at prices that farmers could afford. ${ }^{55}$

Thus, the campaigns against Colorado beetle reinforced the use of lead arsenate in Spain and also introduced new, more disciplined practices in Spanish agriculture, extending the control over farmers' lives and subordinating them to the centralized state thanks to the work of the provincial network of agricultural engineers. While agronomic research provided new ways to manage rural areas, the emerging Francoist regime offered new opportunities for agricultural engineers to supervise pest control. ${ }^{56}$ Apart from the examples mentioned above, further regulations were published by the Department of Agriculture in May 1944: proprietors, workers, agricultural engineers, municipal authorities and even the police (Guardia Civil) were instructed to carefully survey potato fields and report any trace of the pest as soon as possible. This action against the pest was compulsory for landowners, and penalties were imposed on farmers who did not report the pest or did not follow the stipulated procedures. ${ }^{57}$ Alfaro Moreno worried that farmers did not fully understand that the fight against this new pest required permanent daily vigilance and action, which had to be as "common as watering, earthing up and weeding" ("riegos, recalces, escardas"). As potatoes were such an important part of the Spanish diet, Moreno argued, the authorities had to combat all "the forms of ignorant resistance;" farmers who "actively or passively" avoided the implementation of these treatments (that is, arsenical pesticides) should be forced to use them. ${ }^{58}$

In order to offer a more nuanced portrayal of the campaigns let us take an example from the province of Burgos, where potatoes were an important part of agriculture production. Talks were organized in 1941 by the agronomy office on the uses of arsenical pesticides, and some $4000 \mathrm{~kg}$ of lead arsenate was distributed. Even so, considerable resistance was recorded:

\footnotetext{
55 "Aportaciones del Estado en la lucha contra el escarabajo de la patata," Agricultura 13, no. 142 (1944): 88-92. On the role played by the "Hermandades" see Diario de Burgos, 21 July 1944, 2 and Cabo, A estación de fitopatoloxía, 237-238. See José María Gómez Herráez, "Las hermandades sindicales de labradores y ganaderos (1942-1977): del análisis franquista a la historiografía actual," Historia agraria 44 (2008): 119-55.

56 On the co-production of agronomic research and fascist states, see Saraiva, Fascist Pigs; Camprubí, Engineers and the Making of the Francoist Regime, 77-101.

57 "Orden de 11 de mayo de 1944 sobre medios de defensa contra la plaga del escarabajo de la patata," BOE, 15 May 1944, 3892-2803.

58 Alfaro Moreno, Una Calamidad Pública, 4-5.
} 
farmers were reluctant to report the plague, in the fear that their harvests would be burned. ${ }^{59}$ The Francoist provincial authorities (the office of the Gobernador Civil) organized a Provincial Defense Office against the Potato Beetle (Junta Provincial de Defensa contra el Escarabajo de la Patata) and local brigades were sent to rural areas to detect and remove the plague. Women and children were obliged to help in detecting and removing the beetles by hand before the fumigations. The Junta also provided large quantities of lead arsenates and apparatus for fumigation, while encouraging the farmers to buy these products. ${ }^{60}$ In the knowledge that many farmers had not followed the guidelines in previous campaigns, the Gobernador Civil published orders announcing that all infringers were to be punished most severely, including mayors who failed to report their fellow farmers; they would be interned in "concentration camps," their crops confiscated by the government, and their lands offered to other more obedient countryfolk. ${ }^{61}$

The example of the province of Burgos confirms that the programme for controlling the Colorado beetle pest was based on a combination of sociotechnological products (such as lead arsenate), expert advice (agricultural engineers), agropolitical propaganda and ruthless repression. In this oppressive atmosphere, expressions of disconformity were few and far between. The socialist, anarchists or republican trade unions, which had been so important in the rural world during the 1930s, were suppressed, and many peasant leaders killed or exiled. Nevertheless, some traces of resistance can be found between the lines of the expert reports, and repressive measures were indeed taken against discontented and unruly peasants. ${ }^{62}$ Farmers were reluctant to use arsenical pesticides due to the uncertainty regarding their effects, the costs involved (in terms of chemicals, apparatus and labour hours) and the dangers to cattle (particularly on small farms). By the mid-1940s, when the new organic pesticides arrived, arsenic compounds were in use in the larger landholdings, but small farmers remained unenthusiastic about adopting these new products. ${ }^{63}$

As in other countries, the intensive use of agrochemicals reinforced the unequal distribution of resources in rural areas, favouring the accumulation of capital by great landowners and causing serious danger to agricultural workers. The large landholdings (the latifundios) were

59 Eufemio Olmedo, “Memoria sobre la campaña de plagas del campo del año 1941," December 1942, AGA, 61/822.

${ }^{60}$ FET y de las JONS. Delegación provincial de sindicatos, "Ordenanzas a que ha de ajustarse la campańa contra el escarabajo de la patata en la provincia," Burgos, 26 May 1944, AGA, 61/823. On similar activities organized by the Nazis in Germany, see Saraiva, Fascist Pigs, 87-90.

${ }^{61}$ Order signed in Burgos, 17 May 1944 by Manuel Yllera García-Lago. Diario de Burgos, 18 May 1944, 1.

${ }^{62}$ For different form of everyday resistance in rural areas during the 1940s, see Ana Cabana Iglesia, $L a$ derrota de lo épico (Valencia: PUV, 2013).

${ }^{63}$ Eufemio Olmedo, "Memoria justificativa del presupuesto de 1946," Burgos, 27 October 1945, AGA $61 / 822$. 
more prepared for monoculture crops, which were more vulnerable to pests, but were also well suited to the intense use of agrochemicals and mechanization. Their owners (latifundistas), who had been alarmed by the projects of land distribution ("Reforma Agraria") in the 1930s, were among the most influential groups supporting the Francoist regime in the 1940s. Moreover, they were able to invest in sprayers and chemicals without considering the human costs of toxic products in their cost/benefit analysis, and received the support of the agricultural engineers who legitimized this econometric approach. In contrast, small farmers and mere farm workers could hardly ignore the toxic effects when assessing the advantages and disadvantages of arsenical pesticides. ${ }^{64}$

Facing these resistances, agricultural engineers used three types of argument to encourage the use of arsenical pesticides: the rhetoric of costs and benefits, military metaphors, and the mixture of patriotic discourse with modernizing ideas. They argued that the cost of pesticides was much less important than the damage produced by the pest in the fields. "Money for [chemical] pest control is one of best productive investments that farmers can make because, even in the worse cases, the right treatment will allow them to recoup at least three or four times the money invested," claimed Miguel Benlloch. ${ }^{65}$ Small-scale studies of costs and benefits performed in controlled fields confirmed the advantages of the new pesticides. ${ }^{66}$ Even so, it was acknowledged that the new treatments and the labour costs would push up production costs, and agricultural engineers were worried about the policy of fixed prices. Significantly, these economic estimates never considered the human costs or the health hazards. ${ }^{67}$

Agricultural engineers also used military language to describe pest control, speaking of enemies, invaders, armies, containment, blockades, combat, annihilation, extermination, and so on. Alfaro Moreno described the potato beetle pest as "the vanguard and even the bulk of a true army," which was "invading" Spain from the French border ("the potential area of

\footnotetext{
${ }^{64}$ On these issues see Wright, The Death of Ramón González; Murray, Cultivating Crisis. On Spanish landownership in these years, see Carlos Barciela López, "La contrarreforma agraria y la política de colonización del primer franquismo, 1936-1959," in Reformas y politicas agrarias en la historia de España, eds. Ángel García Sanz and Jesús Sanz Fernández, 351-98 (Madrid: Centro de Publicaciones Agrarias, Pesqueras y Alimentarias, 1996); Carlos Barciela López, "El trágico final de la reforma agraria. La revolución fascista en el campo español," in En el combate por la historia: la república, la guerra civil, el franquismo, ed. Angel Vińas Martín, 335-54 (Madrid: Pasado y Presente, 2012).

${ }_{65}$ Miguel Benlloch, "Aspecto económico de la lucha contra las plagas," Boletín de Patología Vegetal y Entomología Agrícola 10 (1941): 275-88.

${ }^{66}$ Eufemio Olmedo, "Memoria sobre la campaña de plagas del campo del año 1944," Burgos, 11 April 1945, AGA, 61/823. See also Dirección General de Agricultura, Plagas del Campo. VII. Los Servicios de Fitopatología y Plagas del Campo. Bosquejo de su actuación en el periodo 1939-49 (Madrid: Agricultura, 1953), 111-13.

${ }^{67}$ Agustín Alfaro Moreno, "Insistiendo sobre el escarabajo de la patata," Agricultura 13, no. 142 (1944): 88-92.
} 
penetration") using "the natural lines which offered the best opportunities for advance." ${ }^{68} \mathrm{~A}$ documentary, produced by the director of the Service for Agrarian Cinematography with the help of Miguel Benlloch, portrayed the Colorado beetles as paratroopers descending from aircrafts, invading peaceful Spanish villages and destroying their crops. ${ }^{69}$

In this context, agriculture engineers also mobilized patriotic feeling, connecting it to ideas of regeneration and technological modernization - common tropes in the fascist rhetoric of the time. The campaign against the Colorado beetle accompanied the ruthless repression of political dissent, and sometimes used similar images, metaphors, and propaganda. The battles against dangerous pests and human dissidents were both marked by the patriotic goal of exterminating the enemy with the regenerating power of the new authoritarian regime; farmers who failed to spray were enemies both of the nation and of progress in the new national-syndicalist State. ${ }^{70}$

\section{Creating the Spanish pesticide industry}

In their attempts to improve the new fascist biopolitics, the Spanish authorities faced a real problem regarding the supply of pesticides. Before the Civil War, the estimated consumption of pesticides was lower than in other countries; in the case of lead arsenate, it was around 500 tonnes per year in $1935 .{ }^{71}$ One of the reasons for this low consumption of lead arsenate was its high price, as it had to be imported from abroad. World War II choked off the supply of pesticides - not only of arsenates but also of cupric sulphate, crucial for the fungicide called the "Bordeaux mixture," and sodium cyanide, used in the fumigation of citric trees. According to an official report, just 115 tonnes of lead arsenate were imported in the years 1941-42, and a similar amount of all the other arsenates (Paris green, sodium arsenate, etc.). The author noted that the potato beetle pest had produced "an unexpected increase in the consumption of arsenates," which had to be "irremediably faced," because it affected such a "basic and essential" crop. The government attempted to maintain the imports of arsenates while promoting "national production in the making." "2

\footnotetext{
${ }^{68}$ See Alfaro Moreno, "El escarabajo de la patata." On pesticides and War: Edmund Russell, War and Nature: Fighting Humans and Insects with Chemicals from World War I to Silent Spring (Cambridge: Cambridge University Press, 2001).

${ }^{69}$ Marqués de Villa-Alcázar, "El cine aplicado a la divulgación agrícola," Revista Española de Pedagogía 9, no. 34 (1951): 311-20; Pedro Poyato Sánchez, "La dimensión política de los primeros documentales del Marqués de Villa-Alcázar," ZER - Revista de Estudios de Comunicación 21, no. 41 (17 November 2016): 209-226.

${ }^{70}$ See, for instance, Daniel Nagore, La patata: el tubérculo de los incas (Pamplona: Aramburu, 1939), 21.

${ }^{71}$ Antonio Comba y Siguenza, Estudio sobre la posibilidad de fabricar en España los arseniatos necesarios para el consumo nacional (Madrid: Gráficos Reunidos, 1942), 1-2.

72 "Importaciones de insecticidas durante el año agrícola 1941-42," Agricultura 11, no. 119 (1942): 116-18.
} 
One might have expected the scarcity of pesticides after the Civil War to encourage alternative methods for pest management: biological control, breeding and seed selection, or changes in crop production practices to reduce the likelihood of pest damage. In the previous sections, we have seen that these methods were well known in Spain during the 1930s; in fact, discussing pest control management in 1942, the director of the Madrid Experimental Field Station Miguel Benlloch recommended their use when chemical pesticides were not available. ${ }^{73}$ Benlloch foresaw an important role for biological methods in the future, but the dramatic circumstances of the 1940s and the "enormous economic damage" caused by insects meant that they could not "wait (for such) distant solutions." On the contrary, farmers were compelled to use the "chemical struggle" ("lucha química"), which in spite of "all its flaws ... (achieved) ... more and more numerous developments and successes." 74 This was also the view of Alfaro Moreno. Reviewing the different methods in 1951, he noted that many of them were widely used in Spain before World War II, but he stated that, due to the emergency caused by the Colorado pest and the critical situation of Spanish agriculture in the 1940s, only chemical treatments for plants were truly effective. ${ }^{75}$

Alternative methods for pest control were marginalized in the 1940s for reasons other than those mentioned by Moreno and Benlloch. Unlike biological control, the use of chemical pesticides upheld two of the cornerstones of early Francoist policies: economic self-sufficiency through the use of domestic raw materials (involving a more intensive use of mineral resources), and the development of national industry (in this case, in connection with agriculture). With its material and rhetorical ingredients, autarky helped to justify the new authoritarian regime and its policies of state intervention in the economy, particularly in the key areas of the pharmaceutical industry and food supply. ${ }^{76}$ The role of the new Vertical Labour Union for Chemical Industries (Sindicato Vertical de Industrias Quimica) was crucial in the control of these industries inside the structure of the new corporate State. ${ }^{77}$

Several measures were implemented to promote the Spanish agrochemical industry in the early 1940s. Since important raw materials such as cupric sulphate could not be obtained in

\footnotetext{
${ }^{73}$ Miguel Benlloch, "¿Puede combatirse las plagas prescindiendo de insecticidas y anticriptogámicos?," Agricultura 11, no. 125 (1942): 362-63. For a more positive review of biological methods in these years, see Federico Gomez Clemente, "Los insectos auxiliares en la lucha contra las plagas," Agricultura 11, no. 117 (1942): 5-11.

${ }^{74}$ Miguel Benlloch, Lucha química contra las plagas (Madrid: Estación de Fitopatología Agrícola, 1942).

${ }^{75}$ Agustín Alfaro Moreno, "La invasión del escarabajo de la patata y problemas planteados," Boletín de Patologia Vegetal y Entomología Agrícola 18 (1951): 139-77. On his biography, see Santiago-Álvarez, "El ingeniero agrónomo D. Agustín Alfaro Moreno."

${ }^{76}$ See Saraiva and Wise, "Autarky/Autarchy."

77 On the Spanish pharmaceutical industry during the years of autarky, see Raúl Rodríguez Nozal, "La construcción de una industria farmacéutica autosuficiente en la España de la Autarquía: entre la necesidad, la utopía y la propaganda franquista," Asclepio 69, no. 1 (28 June 2017): 173-189.
} 
the Iberian Peninsula, agricultural engineers studied alternatives, or mixtures involving lesser quantities of these products which had to be imported. ${ }^{78}$ In the case of arsenates, on the other hand, the crisis of the international market was regarded as an opportunity for developing Spanish industry using domestic mineral resources. Just one year after the end of the Civil War, the Geological Institute produced a report regarding the organization of the local production of arsenical mineral resources, which could be used to make pesticides, glazing, and dyes as well as for the "services of chemical warfare." The mining engineer who wrote the report, Antonio Comba y Sigüenza, was a leading member of the fascist national-syndicalist organization. He stressed the opportunities for increasing the extraction of arsenical minerals, particularly in Galicia, which he described as the "Spanish arsenical province" due to the mines of arsenopyrite and the existence of an emerging arsenical industry in the towns of Valdoviño, Teixeiro and Castro de Rei. ${ }^{79}$ In the following years, the use of arsenates rose dramatically. A report covering the decade of the 1940s concluded that the consumption of lead arsenate had increased between six and seven times (up to 3000-3500 tonnes per year). ${ }^{80}$

Another study noted improvements not only in the quantity but also in the quality of national pesticides thanks to the measures implemented by the Francoist government. ${ }^{81}$ As discussed in the previous sections, quality and fraud were other long-term concerns regarding pesticides. For years, agricultural engineers had called for tighter regulations on fraud and adulteration. In 1940 , they managed to set up a permanent programme for the "inspection of the production and commerce of insecticides." ${ }^{22}$ Two years later, the National Register for Phytosanitary Products was created, just months before the establishment of a similar service in Vichy France. As in the French service, the priorities were intensive agricultural production and the development of the pesticide industry, rather than public health concerns. ${ }^{83}$ The register was designed to guarantee the quality of the pesticides: that is, that they should be effective against pests but harmless to plants. No information was requested regarding the hazards for animals, farmers,

\footnotetext{
${ }^{78}$ Cristóbal Mestre Artigas, "Tratamientos contra el mildiu a base de reducir las cantidades ordinarias de sulfato de cobre," Agricultura 10, no. 109 (1941): 161-66; Simón Bartolomé de Diego, "Fórmulas reducidas contra el mildiu," Agricultura 12, no. 132 (1943): 154-56; "Importaciones de insecticidas durante el año agrícola 1941-42," Agricultura 11 no. 119 (1942):116-117. See also the report for the 1940s in Congreso Nacional de Ingeniería Agronómica (Madrid: Asociación Nacional de Ingenieros Agronómos, 1950).

${ }^{79}$ Comba y Siguenza, Estudio sobre la posibilidad de fabricar en España los arseniatos necesarios. On the connections between pesticides and war see Russell, War and Nature.

${ }^{80}$ Dirección General de Agricultura, Plagas del Campo. VII, 111-13. The amount was still low when compared with other similar countries such as France in which 20,000 tonnes of arsenic pesticides were consumed at the end of the 1930s. See Jas, "Public Health and Pesticide Regulation," 372.

81 Pedro Hercé, Condiciones que deben exigirse a los insecticidas arsenicales (Madrid: Ministerio de Agricultura, 1943).

${ }^{82}$ BOE, 4 September 1940, (Order 13 August 1940). See Agricultura 9, no. 96 (1940):137-139.

${ }^{83}$ Jas, "Public Health and Pesticide Regulation," 375-77.
} 
or consumers. The register aimed to encourage national production (a separate procedure was created for imported pesticides, with stricter requirements) as well as to prevent the trading of adulterated products and fakes, which incurred heavy fines. These forms of malpractice were seen as being particularly damaging to the new biopolitics implemented by the agricultural engineers. ${ }^{84}$

The provincial agriculture offices were in charge of reviewing the proposals submitted, the regular inspection of provincial industries, and the control of fraud. A large number of applications were received in 1943 . While a small group were from industries related to pesticides or fertilizers, most of the applications were made by small-scale local producers, in many cases apothecaries, who wanted to produce (or sometimes just to sell) arsenical pesticides. ${ }^{85}$ Applicants frequently stressed that their pesticides contained only "national products." Samples of the pesticides, along with descriptions of the industry, were sent to the Provincial Agriculture Offices, whose directors wrote a preliminary report which focused particularly on the activities of the producers and their capacity for making pesticides in large quantities. Then, samples were sent for analysis to the laboratory run by Miguel Benlloch at the Madrid Phytopathological Station. Benlloch reported the effects of the pesticide in question, the existence of similar products (so as to avoid resale) and certified the absence of any damaging effects for plants; between 1943 and 1950, he analysed more than 900 products. ${ }^{86} \mathrm{~A}$ large number of proposals were rejected, around 28 percent in the first decade. Around 600 pesticides were admitted by the end of 1952, while one hundred more (most of them foreign products) were only accepted "provisionally."

This review illustrates the goals and consequences of the Register of Pesticides during its first years: the development of the national pesticide industry (first in the area of production of arsenical pesticide, and later in the production of organochlorine compounds such as DDT and lindane); control of the quality and efficacy of pesticides (harmless to plants, active against insects); and the concealment of the human costs of toxic pesticides. The Register of Pesticides also reinforced the links between Francoist politicians and agricultural engineers in terms of both pest and social control in rural areas. The final section of this paper will look more closely at the social perceptions of the toxic hazards and the different groups involved in the

\footnotetext{
84 "Decreto de 19 de septiembre de 1942 sobre fabricación y comercio de insecticidas, anticriptogamicidas y material de aplicación,” BOE, 23 October 1942, 8479-78. For previous attempts see also BOE, 9 April 1941.

85 Dirección General de Agricultura, "Expedientes de inscripción de registros fitosanitarios", several dates, AGA, 5845-5846.

${ }^{86}$ Miguel Benlloch, "El servicio de comprobación y registro de productos fitoterapéuticos," Boletín de Patología Vegetal y Entomología Agrícola 18 (1951): 123-29.

${ }^{87}$ Dirección General de Agricultura, Plagas Del Campo. VI. Registro de Productos y Material Fitosanitario, $4-5$.
} 
processes of visibilization/invisibilization of the risks in different areas: occupational illnesses, food poisoning accidents, criminal murders, and wildlife damages. ${ }^{88}$

\section{Visible and invisible hazards}

The marginalization of the human costs of pesticides has been noted in many studies, and not only in the context of authoritarian regimes such as the Franco dictatorship. In her famous book, and thinking in terms of agriculture in the United States, Rachel Carson remarked that "anyone who has watched the dusters and sprayers of arsenical pesticides at work must have been impressed by the almost supreme carelessness with which the poisonous substances are dispensed." 89 The above discussion shows how far Carson's worries apply to the case under discussion here. Along with the accelerated introduction of new products under pressure from the emerging authoritarian regime, many other features commonly regarded as favouring chronic poisoning could be seen in Spanish agriculture during the 1940s: the lack of safety standards, the poor labelling (if any) of pesticides, inadequate protective clothing and washing facilities, illiteracy, and an ignorance of the hazards associated with arsenical pesticides. ${ }^{90}$ However, cases of arsenical poisoning in farmers were not reported and epidemiological data are lacking, so it is difficult to know the human costs of the mass introduction of these pesticides described in this paper. Several issues contributed to this problem. Two of them have already been discussed: the campaign of propaganda carried out by the agricultural engineers (in the form of talks, movies, leaflets, courses, etc.), and the shortcomings of the Register of Pesticides with regard to the reporting of public health hazards. Additional reasons were the difficulty of recording medical evidence of chronic exposure and slow poisoning in workplaces, a challenging task in agriculture. In fact, even in the few cohort studies conducted in the late 1930s in other countries, the connections between lead arsenate exposure and hazards to peasants' health were difficult to make. ${ }^{11}$ In 1930s Spain, physicians acknowledged that, as in industry, occupational safety regulations focused on physical, violent, sudden accidents and

${ }^{88}$ For further discussion of the literature on these four areas, see Bertomeu-Sánchez and Guillem-Llobat, "Living in a Toxic World (1800-2000)."

${ }^{89}$ Rachel Carson, Silent Spring (Houghton: Riverside Press Cambridge, 1962), 18.

${ }^{90}$ David Pimentel and Hugh Lehman, The Pesticide Question: Environment, Economics, and Ethics (New York: Chapman \& Hall, 1993). See also Wright, The Death of Ramón González; Murray, Cultivating Crisis; Jas, "Pesticides et santé des travailleurs agricoles en France."

91 William C. Nelson, et al., "Mortality among Orchard Workers Exposed to Lead Arsenate Spray: A Cohort Study," Journal of Chronic Diseases 26, no. 2 (February 1973): 105-18. On the history of biomonitoring see Angela Creager, "Human bodies as chemical sensors: A history of biomonitoring for environmental health and regulation," Studies in History and Philosophy of Science Part A, 70 (August 2018): 70-81. 
were ill-conceived for long-term workplace hazards such as chronic intoxications. ${ }^{92}$ Therefore, cases of acute poisoning might sometimes be reported, but the effects of chronic poisoning were hardly ever taken into account. The issue of chronic poisoning among farmers remained silenced until the late 1950s, when agricultural engineers began to publish papers drawing attention to the confusion between acute and chronic intoxications. ${ }^{93}$

The hazards of arsenic products remained visible in other areas: wildlife damage, criminal poisoning, and accidents involving arsenic in food. Even in the early Francoist years, certain criticisms were published concerning the effects of arsenates on wildlife. In 1944, when the arsenate campaign against the Colorado beetle had reached its peak, an anonymous hunter wrote a letter to a magazine complaining of the ambivalent attitudes of farmers: some of them were satisfied with the arsenical treatments, while others were more sceptical about the results. Farmers might be divided on that matter, he affirmed, but no one doubted the effects on wildlife: "The presence in the fields of these poisons has spared none: neither hares, nor rabbits, nor partridges, nor quails, nor blackbirds, nor turtledoves, nor any other game. The desolation is complete." ${ }^{94}$ Perhaps worried by its possible negative effects on the propaganda campaigns, agricultural engineers responded to this letter both in non-specialist magazines and in publications for farmers. One of the most detailed answers reviewed the experiments performed in France, whose results apparently showed that arsenates were not damaging for wildlife; it also recalled the recent changes in French regulations allowing the widespread use of arsenates in agriculture. ${ }^{95}$

But what really caught the public attention were poisoning crimes and accidents. Previously regarded as the king of poisons, by the second half of the nineteenth century arsenic was no longer used so widely in criminal poisoning. However, as the director of the Madrid Institute for Toxicology acknowledged, the number of cases rose once more during the first third of the twentieth century, due to the "more extended usage of arsenates ... in agriculture." The mass introduction of lead arsenate in the 1940s not only made arsenic compounds more readily

${ }^{92}$ See Vicente de Andrés Bueno, Accidentes del trabajo agricola: estudio médico-legal, Facsimile of the first edition, with an introduction by Agustín Galán García and María Castellano Arroyo (Madrid: Fundación Mapfre, [1933], 2010). For a recent medical work on this issue, see José Luis AgudoMena, José Manuel Azaña-Defez, Eva María García-Atienza, and María Encarnación Gómez-Sánchez, "Pesticidas arsenicales como causa infrecuente de carcinoma basocelular en paciente octogenario," Revista española de geriatría y gerontología 53, no. 1 (2018): 56-57.

${ }^{93}$ Two examples of papers published by agricultural engineers are Miguel Benlloch, "Peligro de accidentes por el manejo y empleo de productos fitoterapéuticos," Boletín de Patología Vegetal y Entomología Agrícola 22 (1956): 175-80; José María Rivero, "Toxicología de los productos fitoterapéuticos. Sus consecuencias para la salud del hombre y del ganado," Boletin de Patologia Vegetal y Entomologia Agricola 24 (1959): 73-88.

${ }^{94}$ E[ugeni] Casadevall, "Cartas al director [Los arsenicales y la caza]," Destino, 28 October 1944.

95 "Los arsenicales y la caza," Agricultura 13, no. 151 (1944): 653-54. On France see Jas, "Public Health and Pesticide Regulation." 
available for criminal purposes, but also increased the rates of unfortunate accidents and food poisoning. ${ }^{96}$ The most famous case of criminal poisoning involving arsenates took place in 1935, not far from the site of the first invasion of Colorado beetles in northern Catalonia. A woman was accused of using arsenate compounds to poison her relatives. She had no difficulty obtaining calcium arsenate at the apothecary, claiming that she needed it for pest control. The trial was reported in full detail in the local and national press. ${ }^{97}$ Many other cases of arsenic poisoning protagonized by maidservants caused great alarm. One of the most famous dated from the 1950s, when Pilar Prades, a servant accused of poisoning several people, was garrotted - the last woman to be executed in Spain. ${ }^{98}$

In contrast with these high-profile poisoning crimes, neither journalists nor judges paid any attention to a large poisoning incident in the small village of Pradoluengo (Burgos) during the summer of 1946, which affected more than 200 people. At least one person died and five others suffered acute neuropathic damage, in the form of sensory and motor deficits. An inquiry was launched, which was carried out by several physicians and pharmacists without any help from the judiciary or the Francoist authorities. The inquiry concluded that the victims had been poisoned by drinking wine adulterated by lead arsenate (which had been confused with plaster, the regular additive). Local doctors, with the help of the Provincial Public Health Service, organized the collection of samples which were sent to the Municipal Laboratory in Burgos. Fearing that other batches might also be affected, the director of the Burgos laboratory set up a network of apothecaries to perform analyses of wines all over the province and wrote a practical guide with instructions concerning both the collection of samples and chemical tests. He suggested an "easy-to-perform" method (a simplified version of the Gutzeit test introduced in the early twentieth century), which required neither special skills nor equipment, and which he had been previously tested himself, "with excellent results." The final results confirmed traces of arsenic in other samples. The final report was written by Ignacio López Saiz, a psychiatrist, who described the neurological damage produced by arsenic, and reviewed the international literature on the hazards of chronic exposure and the risks of accidents. López Saiz concluded that measures had to be taken to avoid future confusions of lead arsenate with common products used in food and drink. ${ }^{99}$ Some minor regulations concerning arsenic products were introduced at the end of 1946: lead arsenate could no longer be sold in grocery stores, and the sacks containing it had to be labelled "highly poisonous," in large red letters, and could not be

${ }^{96}$ Eugeni Sellés, "Las intoxicaciones en España en el decenio 1926-1935," Anales de Física y Química 36 (1940): 102-5.

${ }^{97}$ La Tribuna, April 26, 1935; Crónica, May 19, 1935.

98 See José Ramón Bertomeu-Sánchez, "Criminal poison and pesticide: Arsenic in Francoist Spain," (forthcoming)

99 Ignacio López Saiz, “Intoxicación Arsenical Colectiva," El Siglo Médico 93, no. 115 (1947): 29-37. See López Gómez López, "Intoxicación colectiva por arsénico en el Pradoluengo de la postguerra (1946)," Boletín de la Institución Fernán González 88, no. 238 (2009): 35-44. 
reused for storing foodstuffs. ${ }^{100}$ Other measures proposed by López Saiz, including the placing of lead arsenate under the control of pharmaceutical institutions, and "denaturalizing" it (with colouring or fragrances) in order to avoid confusion with foodstuffs, were rejected. ${ }^{101}$

At almost the same time, and just few months after the large-scale accident in Pradoluengo, further regulations for phytosanitary products were published that focused specifically on arsenate compounds. These regulations were based on research performed by agricultural engineers at the experimental field stations, involving careful laboratory analysis of different mixtures of arsenates and their effects on plants and insects. ${ }^{102}$ Once again the new regulations aimed to control the efficiency of insecticides on pests and to ensure their harmlessness to plants. No references to human or animal toxicity were included. ${ }^{103}$

In contrast to the limited scope of the previous regulations, which did not include all the recommendations made by the doctors, the supervision of the quality of pesticides rapidly incorporated new data from the research performed by agricultural engineers in the 1940s. No similar programme of research was carried out on the effects of chronic exposure to arsenic in farmers or in ordinary consumers. Cases of arsenic poisoning remained silenced and unreported; the clinical effects were confused with other common symptoms, and no preventive measures were ever taken. ${ }^{104}$

\section{Conclusions}

The above section sheds light on the striking inequalities involved in the production of knowledge and ignorance regarding pesticides and their hazards in the early Francoist years. Public health doctors faced many difficulties recording epidemiological information, as they lacked the support of the legal or political authorities. And even when the data reported were alarming, as in the Pradoluengo accident, the medical evidence was ignored or resulted in insufficient public action to prevent the risks to consumers and farmers; in contrast, new research on pest quality control was very quickly used to introduce changes in the regulations. Agricultural engineers were provided with ideal resources for their research in the form of experimental field stations and chemical laboratories, and they also managed a large network

100 "Orden de 2 de diciembre de 1946 por la que se prohíbe la venta de arseniato de plomo u otros productos similares en los establecimientos donde se expenden substancias alimenticias. Ministerio de la Gobernación,” BOE, 7 December 1946.

${ }^{101}$ Ignacio López Saiz, "Intoxicación Arsenical Colectiva," 37.

102 Pedro Hercé, Condiciones que deben exigirse a los insecticidas arsenicales; Pedro Herce, Análisis de insecticidas (Madrid: INIA, 1945).

103 “Orden 26 November 1946," BOE, 7 December 1946.

104 "Chronic poisoning in farmers using arsenical sprayers was included in the list of occupational diseases in 1978”. See BOE, 25 August 1978. 
of provincial agronomic offices which provided them with data for their experimental projects in the fields. In addition to the courses and other propaganda activities, agricultural engineers also received support from the political authorities in their attempts to persuade farmers to use arsenical pesticides. So in the early years of the dictatorship, agricultural engineers were able to apply their research in decision-making processes, so successfully promoting the creation of long standing regulations such as the Register of Pesticides.

In this propitious context, arsenical spraying was introduced very quickly and extensively in farming. Agricultural engineers had designed their programmes for pest control during the previous decades, in collaboration with other groups involved in pest control management: forest engineers, entomologists, public health physicians. In contrast to some of the leading members of these professions, few agricultural engineers were affected by the political repression which followed the Spanish Civil War. Some of them were able to obtain laboratory resources and permanent positions during the first years of the dictatorship and, even more importantly, were in close contact with policy-makers. While enjoying these advantages for their career development, agricultural engineers also helped to consolidate the new Francoist regime by providing technological solutions for the food crisis, and by using domestic raw materials to bring together agriculture and industry in this period of autarky. With the availability of arsenic mineral resources in the north of the country, arsenates became a convenient sociomaterial product for developing these policies; other pesticides, for instance cupric sulphate, would have had to be imported. Similarly, other methods of pest control which had been widely explored in the 1930s could not be used to develop an industry based on national resources in tune with the Francoist policies of self-sufficiency.

With the help of the arsenical pesticides, both agricultural engineers and the new political authorities could present themselves as the defenders of the Spanish fields from the Colorado beetle invasion, using language similar to that used to describe the subversive groups of the Second Republic. Like the battle against political dissidence, the war on insects was portrayed by fascist propagandists as a survival campaign for the Spanish nation: disciplining recalcitrant farmers by means of new technoscientific practices was a patriotic necessity to protect the food supply during the years of famine and to stimulate the emerging Spanish industry. Like the thousands of political dissidents who were buried in mass graves and condemned to oblivion, the human costs of the mass introduction of arsenical pesticides were concealed by the practices of propaganda, invisibilization, and public inaction described in this paper. From this perspective, lead arsenate spraying can be regarded as a form of "slow violence," very much in consonance with other more visible forms of political violence and technologies for social control in the rural areas during the 1940s. Our discussion confirms that the promotion of 
these dangerous pesticides was "intimately tied to the political relationships and the ideological assumptions" of the early Francoist governments. ${ }^{105}$

How idiosyncratic was the Spanish path to the "pesticide treadmill" described in this paper? Like other sociotechnological products or organisms, lead arsenate was employed elsewhere in very different social and cultural contexts, both under dictatorships and in democracies. In Spain the use of arsenical pesticides persisted long after the end of the sociopolitical context of the early Francoist years; they continued to be applied in Spanish farming (and were still found in farmers' bodies) for many decades after the end of the autarkic policies, even when organochlorine pesticides took over in the 1950s. Once introduced - by brute force, technological persuasion, or political propaganda - arsenical pesticides became unruly and invisible residues which defied all regulation. ${ }^{106}$ As they became part of the everyday practices of agriculture, they silently increased the inequalities in the distribution of toxic exposure; they also reinforced the position of the landowners, the chemical industry and the authorities, and the role of agricultural engineers as expert advisers. Resistance to these developments was difficult, although many critical voices have been found in the documents reviewed in the previous pages: farmers fearing the hazards to their crops, cattle and families; doctors treating the victims of poisoning accidents, and hunters concerned about the effects of the toxins on wildlife. These groups faced large areas of ignorance concerning the hazards (for instance, the lack of epidemiological data on chronic poisoning) and even when they managed to collect conclusive evidence, as in the Pradoluengo accident, it was practically impossible for them to make their voices heard and thus to transform the available toxicological knowledge into decision-making. The discussion confirms that pesticides are intensely political products connecting humans and non-human organisms in contested relationships which, in the context studied here, were marked by forms of visible and invisible violence.

\section{Acknowledgements}

I would like to thank the two anonymous reviewers of this paper as well as Salvador Calatayud (University of Valencia) for his kind suggestions and critical comments and Mike Maudsley for his help in checking the English text.

\footnotetext{
${ }^{105}$ Quoted from Wright, The Death of Ramón González, 217. See also Rob Nixon, Slow Violence and the Environmentalism of the Poor (Cambridge: Harvard University Press, 2011).

106 Soraya Boudia, et al., "Residues: Rethinking Chemical Environments," Engaging Science, Technology, and Society 4 (2018): 165-78.
} 